\title{
Glycine and glycine receptor signalling in non-neuronal cells
}

\author{
Jimmy Van den Eynden ${ }^{1}$, Sheen Saheb Ali ${ }^{1}$, Nikki Horwood ${ }^{2}$, Sofie Carmans ${ }^{1}$, Bert Brône ${ }^{1}$, Niels Hellings ${ }^{1}$, \\ Paul Steels' ${ }^{1}$ Robert J. Harvey ${ }^{3}$ and Jean-Michel Rigo ${ }^{1 *}$
}

Institute of Biomedical Research, Hasselt University and transnationale Universiteit Limburg, Diepenbeek, Belgium

2 Kennedy Institute of Rheumatology Division, Faculty of Medicine, Imperial College London, Charing Cross Campus, London, UK

${ }^{3}$ Department of Pharmacology, School of Pharmacy, University of London, London, UK

\section{Edited by:}

Jochen C. Meier, Max Delbrück Center

for Molecular Medicine, Germany

\section{Reviewed by:}

Luis Aguayo, Universidad de

Concepción, Chile

Claudia Eder, University of London, UK

*Correspondence:

Jean-Michel Rigo, Institute of

Biomedical Research, Hasselt

University and transnationale

Universiteit Limburg, Agoralaan,

Building C, B-3590 Diepenbeek,

Belgium.

e-mail: jeanmichel.rigo@uhasselt.be
Glycine is an inhibitory neurotransmitter acting mainly in the caudal part of the central nervous system. Besides this neurotransmitter function, glycine has cytoprotective and modulatory effects in different non-neuronal cell types. Modulatory effects were mainly described in immune cells, endothelial cells and macroglial cells, where glycine modulates proliferation, differentiation, migration and cytokine production. Activation of glycine receptors (GlyRs) causes membrane potential changes that in turn modulate calcium flux and downstream effects in these cells. Cytoprotective effects were mainly described in renal cells, hepatocytes and endothelial cells, where glycine protects cells from ischemic cell death. In these cell types, glycine has been suggested to stabilize porous defects that develop in the plasma membranes of ischemic cells, leading to leakage of macromolecules and subsequent cell death. Although there is some evidence linking these effects to the activation of GlyRs, they seem to operate in an entirely different mode from classical neuronal subtypes.

Keywords: glycine receptor, cytoprotection, glia, immune cells, renal cells, hepatocytes, endothelial cells

\section{INTRODUCTION}

Glycine is one of the main components that mediate fast inhibitory neurotransmission in the central nervous system (CNS). Whilst gamma-amino butyric acid (GABA), interacting with $\mathrm{GABA}_{\mathrm{A}}$ receptors $\left(\mathrm{GABA}_{\mathrm{A}} \mathrm{Rs}\right)$ acts on the rostral part, glycine-mediated transmission operates in the caudal part of the CNS (brain stem and spinal cord). Activation of glycine-gated ion channels (GlyRs) leads to postsynaptic hyperpolarization induced by chloride influx, or a shunt effect characterized by a drop in membrane resistance consecutive to enhanced chloride conductance. GlyRs are pentameric proteins belonging to the cys-loop family of ligand-gated ion channels. GlyRs are able to form homomeric receptors, composed of $\alpha$ subunits, or heteromeric receptors, composed of $\alpha$ and of $\beta$-subunits and in a putative $3 \beta / 2 \alpha$ or $2 \beta / 3 \alpha$ stoichiometry (Grudzinska et al., 2005). Four different subtypes of $\alpha(\alpha 1-\alpha 4)$ and one $\beta$ subunit, encoded by separate genes, have been described to date in most species. GlyRs are typically considered to consist of $\alpha 1 \beta$-heteromers in the mature spinal cord and brainstem, whilst in the foetal/neonatal nervous system homomeric $\alpha 2$ subunit GlyRs are suggested to predominate (for reviews see Betz and Laube, 2006; Kirsch, 2006; Legendre, 2001; Lynch, 2004). However, the GlyR $\alpha 3$ subunit has recently emerged as a key players in inflammatory pain pathways in the spinal cord dorsal horn (Harvey et al., 2004), and it is clear that we do not yet know the full extent of locations and cell types expressing GlyRs. Increasing evidence suggests that inhibitory neurotransmitters, including glycine, exert a more general signalling role than the pure transmission of neuronal inhibition, both within and outside the nervous system. In this respect, it is important to note that GABA and glycine play a key role in developmental processes in neural stem cells and progenitors (reviewed in Nguyen et al., 2001). In this review we focus on non-synaptic roles of glycine and GlyR-mediated signalling in non-neuronal cell types and organs, describing the potential mechanisms of action and biological roles of GlyRs in these cell types.

\section{NEUROGLIAL CELLS}

Ontogenetically, neuroglial cells in the CNS can be divided into ectodermal-derived macroglial cells (oligodendrocytes and astrocytes) and mesodermal-derived microglial cells. Macroglial cells have the same embryonic origin as neurons. The first reports of neurotransmitter receptors in oligodendrocytes and astrocytes suggested that no functional GlyRs were present on these cell types (Gilbert et al., 1984; Kettenmann et al., 1984a,b). However, ionotropic GABA receptors were detected, which mediate depolarizing currents upon ligand binding. This depolarization is explained by GABAinduced chloride efflux, due to the expression of the $\mathrm{Na}^{+}-\mathrm{K}^{+}-\mathrm{Cl}^{-}$ co-transporter (NKCC1) leading to a high intracellular chloride concentration and, hence, to a less negative Nernst potential for chloride (Hoppe and Kettenmann, 1989; Kettenmann et al., 1987). Around ten years later, molecular and functional studies demonstrated that macroglial cells harbour functional $\alpha 1 \beta$ GlyRs when studied ex vivo in spinal cord slices (Kirchhoff et al., 1996; Pastor et al., 1995). The apparent contradiction with previous in vitro studies may be related to cell culture conditions, which might lead to GlyR down regulation. In this context, excess glycine in certain types of cell culture medium has previously been linked to cell death in heterologous GlyR expression experiments (Groot-Kormelink et al., 2002). Nguyen and Belachew further demonstrated, in their oligodendrocyte and neurosphere models, that both GlyRs and glycine transporters (GlyTs) were molecularly and functionally present at different stages of macroglial development (Belachew et al., 1998a,b, 2000; Nguyen et al., 2002). In oligodendrocyte progenitors, glycine was found to depolarize the cell membrane, via the activation of both GlyRs and GlyTs. This depolarization led to the 
activation of voltage-gated calcium channels (VGCCs) and, hence, calcium influx. This calcium influx may be one of the crucial signals in the development of oligodendroglial cells. GlyT1 and GlyRs containing the $\alpha 1$ and $\beta$ subunits were also described in retinal Müller cells. In these cells, glycine was shown to have a depolarizing effect, suggesting an important signalling role in potassium siphoning, or in the regulation of synaptic glycine concentrations (Du et al., 2002; Lee et al., 2005). Our group also found molecular evidence for GlyR expression in different oligodendroglial cell lines (MO3.13, OLN-93, HOG), although the receptors appear to show a cytoplasmic location, which might explain why we could not detect any GlyR-mediated ionic currents (Sahebali et al., 2007). In this respect, Nguyen et al. also found a discrepancy between the number of cells that express GlyRs (80\%) and those that exhibit glycine-induced currents (33\%; Nguyen et al., 2002). A cytoplasmic location for GlyRs has previously been described in spinal cord neurons (Bechade et al., 1996) and although little is known about GlyR trafficking, it was shown that GlyRs can be ubiquitinated, causing receptor internalization and proteolysis (Buttner et al., 2001). Also chronically blocking GlyR activity with strychnine $(1-10 \mu \mathrm{M})$ was demonstrated to cause receptor internalization (Levi et al., 1998). Since glycine-gated currents are detected in tissue slices while they are absent in individual cell cultures, one could speculate that GlyRs are present in macroglial cells, but that their plasma membrane location and, hence, their functionality is dependent upon cell culture conditions. It seems indeed likely that some unknown factor(s) in the normal physiological environment of slices might be necessary for plasma membrane expression of GlyRs. Further research is however necessary to identify this (these) factor(s). Downstream events of such factor(s) could at least imply protein kinase activity. In that respect, it has been shown that, in the retina and in auditory nuclei, protein kinases modulate strychnine binding and, hence, GlyR expression (Salceda and Aguirre-Ramirez, 2005; Yan et al., 2007). Figure 1 summarizes the current findings on glycine and GlyR signalling in macroglial cells. Glycine transporters, astrocytic GlyT1 as well as presynaptic neuronal GlyT2 are of utmost importance for correct glycine recycling both at glutamatergic and at glycinergic synapses, but fall beyond the scope of this review (see Aragon and Lopez-Corcuera, 2003).

Microglial cells, although of mesodermal origin, are considered here because of their intimate spatial relationships to other glial cells and neurons. Over ten years ago, key studies showed that astrocyte-derived glycine and L-serine (between 10 and $100 \mu \mathrm{M}$ ) modulate microglial activity. Micromolar concentrations of glycine induced morphological changes in microglial cells and enhanced lipopolysaccharide (LPS)-induced secretion of nitrogen oxide (NO), superoxide, acid phosphatase as well as metabolic activity. These studies, however, did not focus on the mechanism of this

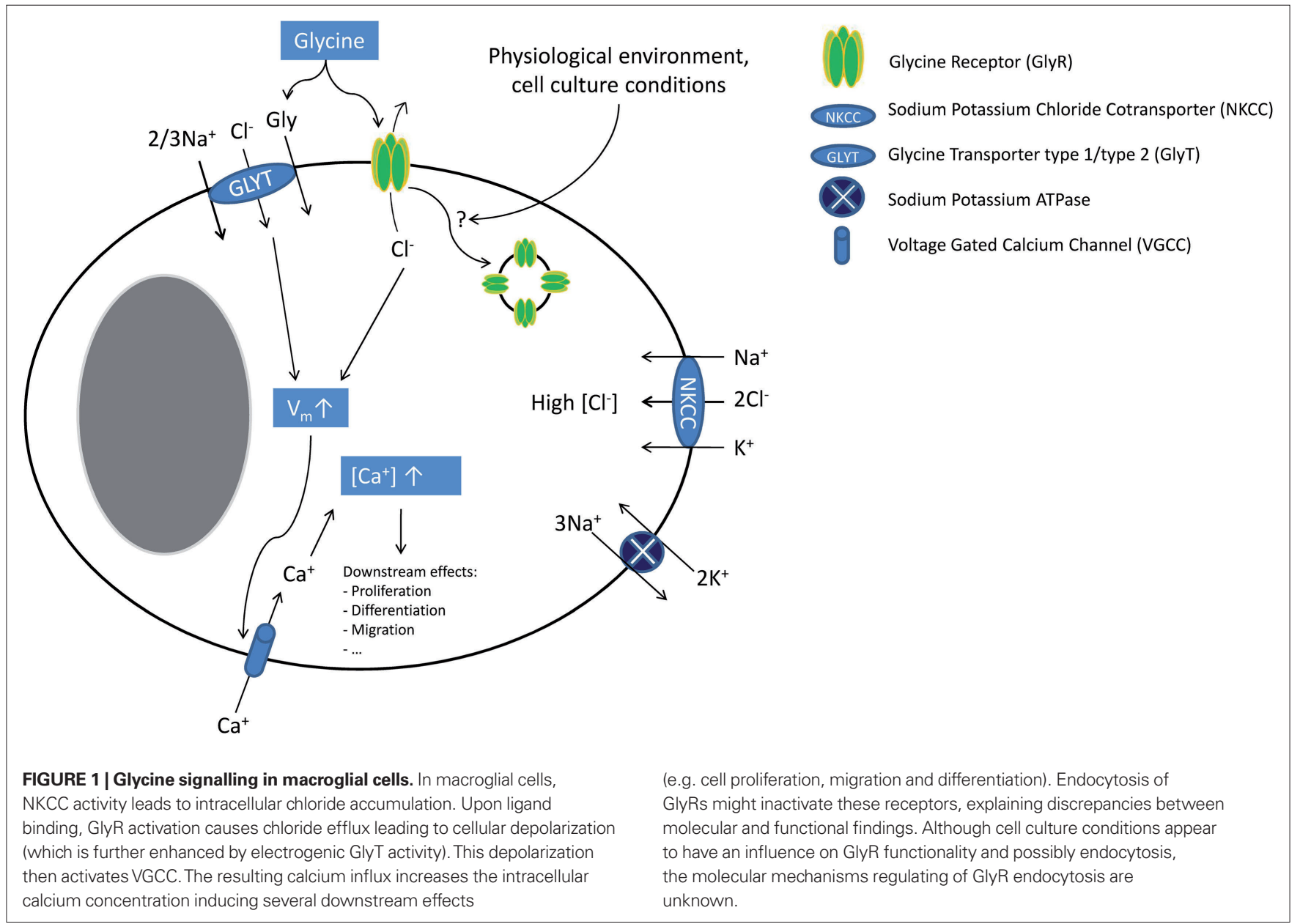


modulatory activity (Tanaka et al., 1998; Yang et al., 1998). Since glycine effects could be mimicked by L-serine, a metabolic precursor of glycine, and since microglial cells were shown to have a low expression of 3-phosphoglycerate dehydrogenase, a key enzyme in L-serine and, hence, glycine biosynthesis, it was suggested that glycine and L-serine could be essential amino acids for microglial cells (Sugishita et al., 2001). This would have implied that the above-mentioned effects could be explained by a metabolic mechanism. This is however contradicted by the high glycine and L-serine synthesis capacities of microglial cells, which seem able to produce glycine and L-serine at concentrations of 88 and $144 \mu \mathrm{M}$, respectively (Hayashi et al., 2006). Another study by Schilling and Eder demonstrated that glycine can depolarize BV-2 microglial cells. Glycine-induced currents were insensitive to strychnine $(1 \mu \mathrm{M})$ or GlyT-antagonists, were chloride-independent and could not be mimicked by the GlyR agonist taurine. Based upon the sodium dependency of glycine currents, their blockade by MeAIB ( $\alpha$-(methylamino)isobutyric acid), the agonist effect of glutamine and their low amplitude, the authors concluded that system A neutral amino acid transporters (SNATs) were responsible for these currents. Moreover, they suggested that these currents, although small, could have a signalling role via membrane depolarization (Schilling and Eder, 2004). Indeed, glycine-induced depolarization was substantial (up to $+30 \mathrm{mV}$ ) despite the low amplitude of the currents (around $10 \mathrm{pA}$ ), and could be explained by the high membrane resistance of microglial cells (Newell and Schlichter, 2005). Although these data suggest that functional GlyRs are not present on microglial cells, our group recently provided molecular evidence for $\alpha$ and $\beta$ GlyR subunit and gephyrin expression in these cells ( $\mathrm{J}$. Van den Eynden, unpublished results). However, the role of these GlyRs remains elusive. Indeed, we also confirmed that the above-mentioned findings in microglial cells were GlyR-independent (Van den Eynden et al., 2008). By analogy with macroglial cells, the discrepancy between molecular and functional data might be explained by cell culture conditions and/or GlyR down-regulation. Future research on brain or spinal cord slices and GlyR trafficking will be necessary to examine this hypothesis.

\section{CONCLUSION}

Astrocytes, oligodendrocytes and microglial cells are intimate partners of neurons in the neuronal microenvironment. GlyRs (and GlyTs) have been described on different developmental stages of macroglial cells where they may have a developmental role in the immature CNS, as well as a communication function in the mature CNS. Glycine signalling in microglial cells may be mediated by non-specific amino acid transporters. However, the biological and functional role(s) of microglial GlyRs remain unknown.

\section{IMMUNE CELLS}

In recent years, it has become obvious that glycine has immunomodulatory effects on different immune cells. As a common feature, inhibition of immune function was found in most in vitro studies, explaining the beneficial effects of glycine that were found in animal studies. For reviews on glycine immunomodulatory effects, the reader can also consult (Wheeler et al., 1999; Zhong et al., 2003). Glycine effects on immune cells have been mainly studied in macrophages, in particular using Kupffer cells, the resident macrophages of the liver. When rat were fed with a diet containing $5 \%$ glycine for 3 days and then subjected to intravenous LPS injection (an animal model of endotoxic shock), a significant decrease in mortality, liver necrosis, lung damage and serum tumour necrosis factor $\alpha$ (TNF $\alpha$ ) levels were found (Ikejima et al., 1996). These beneficial effects were mainly attributed to the inhibitory effects of glycine on Kupffer cells. It was also shown that glycine (0.1$1 \mathrm{mM}$ ) blunted LPS-induced calcium fluxes in Kupffer cells, an effect that could be reversed by low concentrations of strychnine $(1 \mu \mathrm{M})$ and that was not present when a chloride-free buffer was used. Furthermore, glycine was also able to induce uptake of ${ }^{36} \mathrm{Cl}^{-}$ by Kupffer cells (Froh et al., 2002; Ikejima et al., 1996, 1997), an effect that could be mimicked by taurine and $\beta$-alanine, two GlyR agonists (Seabra et al., 1998). These findings clearly suggest a role for GlyRs in modulating Kupffer cell functions. Since fluorimetric measurements showed that LPS depolarized Kupffer cells while glycine hyperpolarized them, it was suggested that GlyR-dependent hyperpolarization leads to an inhibition of functional VGCC, which were also found in Kupffer cells (Hijioka et al., 1992). More recently, glycine was shown to inhibit Toll-like receptor 4 upregulation after LPS exposure in Kupffer cells, showing that other signalling pathways may operate in these cells (Xu et al., 2008). Finally, GlyR $\alpha 1, \alpha 4$ and $\beta$ subunit transcripts and proteins were detected in Kupffer cells (Froh et al., 2002). All the above-described glycine effects on Kupffer cells may explain why glycine is beneficial when co-administered in D-galactosamine and ethanol-induced hepatotoxicity models (Bruck et al., 2003; Stachlewitz et al., 1999; Yamashina et al., 2005). It was indeed shown that ethanol increases gut permeability and hence endotoxine uptake, leading to Kupffer cell activation and secretion of cytokines (e.g. TNF $\alpha$ ), responsible for liver toxicity (Wheeler, 2003). In alveolar macrophages, glycine was also found to blunt calcium fluxes, to increase ${ }^{36} \mathrm{Cl}^{-}$uptake and to decrease superoxide and TNF $\alpha$ secretion. The sensitivity of alveolar macrophages to glycine was higher than for Kupffer cells ( $\mathrm{IC}_{50} \approx 10 \mu \mathrm{M}$, versus $\approx 300 \mu \mathrm{M}$ in Kupffer cells). One suggestion for this finding was that, due to the lower alveolar extracellular glycine concentration, there might be less GlyR down-regulation and, hence, a higher GlyR density on alveolar macrophages (Wheeler and Thurman, 1999). This hypothesis was confirmed by animal studies where rats were fed on a glycine-rich diet for 4 weeks. After this period, Kupffer cells had lost their glycine responsiveness, while alveolar macrophages had not, further suggesting GlyR down-regulation after chronic exposure to glycine (Wheeler et al., 2000b). In splenic macrophages similar effects on calcium fluxes and chloride-uptake were observed (Li et al., 2001). Finally, molecular evidence for GlyR $\alpha 2, \alpha 4$ and $\beta$ subunits was found in alveolar and splenic macrophages (Froh et al., 2002). Next to macrophages, also studies concerning glycine effects on other immune cells were conducted. In T lymphocytes, there is conflicting evidence regarding the modulatory role of glycine. Glycine was suggested to have anti-apoptotic effects on MOLT4 cells, a human T lymphoblastic leukaemia cell line, at millimolar concentrations (Franek et al., 2002). Stachlewitz found that glycine dose-dependently inhibited proliferation of rat lymphocytes between 0.1 and $1 \mathrm{mM}$ and blunted concanavalin A induced calcium fluxes. This latter effect could be blocked by strychnine $(1 \mu \mathrm{M})$ or by replacing chloride by gluconate, suggesting the involvement of GlyRs (Stachlewitz et al., 2000). 
The authors hypothesized that GlyR activation hyperpolarized the cells, leading to inhibition of VGCCs. However, this is in contradiction with the high chloride concentration $(30-60 \mathrm{mM})$ reported in lymphocytes, which, together with the reported membrane potential of -50 to $-70 \mathrm{mV}$, should lead to depolarization upon GlyR activation (Pilas and Durack, 1997; Tian et al., 1999). The putative implication of VGCCs in lymphocytes is also controversial since calcium-release-activated calcium channels (CRACs) seem to be far more important for lymphocyte activation (for review see Lewis, 2001). Alternatively, we suggest that these inhibiting effects on calcium fluxes could arise from membrane depolarization induced by a GlyR-mediated chloride efflux. This depolarization would cause both a decrease in the calcium electrical gradient and a decrease in CRAC channel conductance, leading to lower CRACmediated calcium influx. This mechanism was already suggested to explain GABA R-mediated inhibitory effects on calcium fluxes in T lymphocytes (Alam et al., 2006; Tian et al., 1999). The inhibitory effects of glycine on rat lymphocyte proliferation (Stachlewitz et al., 2000) are in contradiction with other studies suggesting that (i) glycine does not influence mitogen-induced proliferation of human peripheral blood mononuclear cells (PBMCs) (Sommer et al., 1994) and (ii) that glycine does not modulate $N$-formylmethionyl-leucyl-phenylalanine (fMLP)- or LPS-induced calcium fluxes in human PBMCs (Alam et al., 2006). A feasible explanation for these apparently conflicting results may be interspecies differences in GlyR expression. In this respect, it is interesting to note that most immune cells studied so far, including T-lymphocytes (J. Van den Eynden, unpublished results) appear to express the GlyR $\alpha 4$ subunit (Alam et al., 2006; Froh et al., 2002). In human, GLRA4 is a pseudogene due to the presence of a premature stop codon in exon 9, which could explain the absence of functional GlyRs in human studies (Simon et al., 2004). Finally, neutrophils also seem to express functional GlyRs. In these cells, glycine inhibits LPS- and fMLP-induced calcium fluxes, increases ${ }^{36} \mathrm{Cl}^{-}$uptake and decreases superoxide production, all effects that were blocked by $1 \mu \mathrm{M}$ strychnine (Wheeler et al., 2000a). Rat neutrophils also appear to express GlyR $\alpha 2, \alpha 4$ and $\beta$ subunits (Froh et al., 2002). In human monocytes, glycine was found to inhibit LPS-induced TNF $\alpha$ and interleukin (IL)-1 secretion and to enhance IL10 secretion, effects that were strychnine sensitive ( $1 \mu \mathrm{M}$; Spittler et al., 1999). Using flow cytometry, we have also found evidence for GlyR $\alpha 2$ subunit expression in human monocytes and in natural killer cells, a cell population where glycine effects were not studied to date (R. J. Harvey and N. J. Horwood, Figure 2).

\section{CONCLUSION}

Effects of glycine were demonstrated on most immune cells. On monocytes, macrophages and neutrophils, glycine inhibits calcium fluxes leading to a decreased secretion of cytokines (e.g. TNF $\alpha$ ). These effects are likely to be mediated by functional GlyRs, although there may be important species differences in subunit composition. Glycine also seems to exert immunomodulatory effects in T lymphocytes, although, in this case, the results are less clear cut.

\section{RENAL CELLS}

In the kidney, several in vitro studies point to cytoprotective effects of glycine against ischemia. The first evidence of such a protective role of glycine came from a study showing that glycine, produced by the metabolism of glutathione (rather than glutathione itself, as previously thought, Paller, 1986), protects isolated proximal tubules against ischemia in a concentration range of $0.25-2 \mathrm{mM}$ (Weinberg et al., 1987). Since hypoxic conditions lead to a decrease of $\beta$-oxidation and, hence, to an increase in acyl-coenzyme A which, in turn, may lead to detergent-like membrane damage, it was initially suggested that glycine effects could be explained by acylglycine formation and, hence, metabolic detoxification. However, it was subsequently shown that this metabolic mechanism plays no major role in glycine-induced cytoprotection (Weinberg et al., 1991a). It
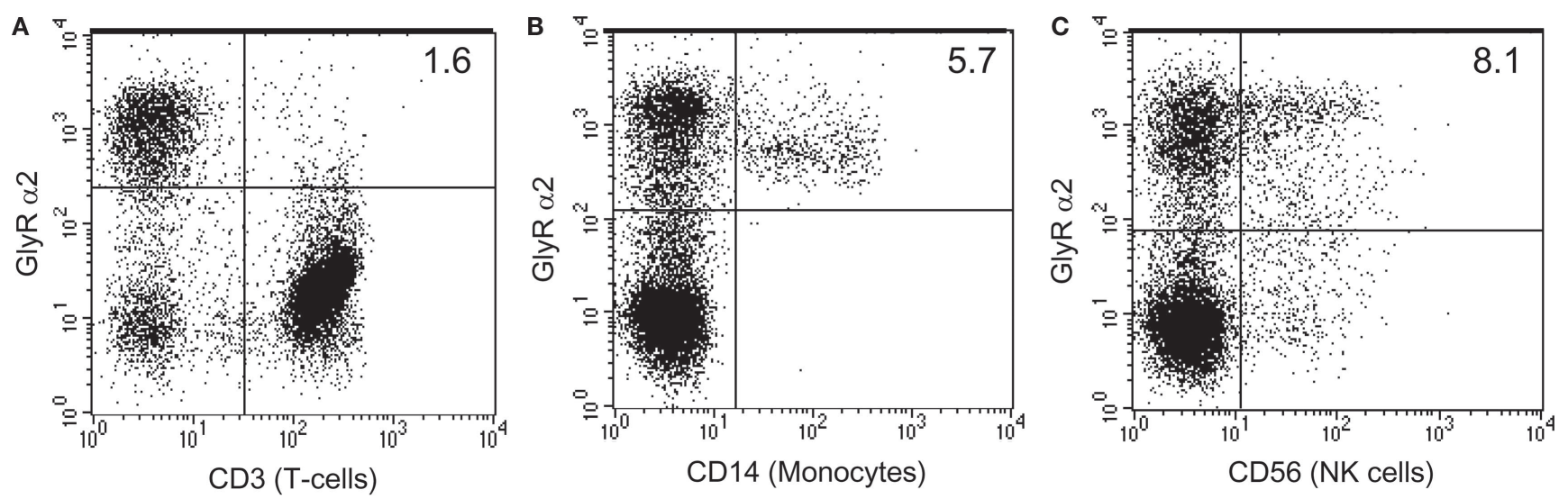

FIGURE 2 | Human monocytes and NK cells express GlyR $\boldsymbol{\alpha} 2$ subunits. Human peripheral blood mononuclear cell subsets were evaluated for the expression of GlyR $\alpha 2$ using a rabbit anti human GlyR $\alpha 2$ antibody (FITC) and either mouse anti-human CD3 (APC), mouse anti-human CD14 (PE) or mouse anti-human CD56 (PE) (BD Pharmingen). Cells were stained according to the manufacturers protocols. GlyR $\alpha 2$ positive cells make up $30 \%$ of the total PBMC population. The T cell population (CD3+) accounts for more than $60 \%$ of the PBMC population and was mostly negative for GlyR $\alpha 2$ expression (A), whilst all of the monocyte population (CD14+) was positive for GlyR $\alpha 2$ (B). More than half of the natural killer (NK) population (CD56+) was positive for GlyR $\alpha 2$ (C). However, since the T cell population was negative, it is likely that the NKT cells are also negative. Cells that were positive for both GlyR $\alpha 2$ and for the lineage specific cell surface marker appear in the top right hand side quadrant. 
was shown that this protection could be mimicked by structurally related amino acids such as L-alanine (Weinberg et al., 1990b), that it was independent of ATP (Weinberg et al., 1997) or calcium (Venkatachalam et al., 1995; Weinberg et al., 1991b) and that it does not protect either against swelling of ischemic cells (Weinberg et al., 1990a) or against plasma membrane breakdown (Venkatachalam et al., 1995). In comparable experimental paradigms, strychnine, in high concentrations $(1 \mathrm{mM})$, was shown to act as an agonist, rather than an antagonist (Aleo and Schnellmann, 1992; Dong et al., 2001). Other GlyR antagonists and chloride channel blockers (e.g. brucine, bicuculline, avermectin B1a, and cyanotriphenylborate) were also demonstrated to exert glycine-like activity (Miller and Schnellmann, 1994; Venkatachalam et al., 1996). Dong and colleagues investigated whether this strychnine protection was due to an (aspecific) intracellular interaction or to an interaction at the cellular membrane, as would be expected for ligand-gated channelmediated actions. They showed that membrane-impermeable strychnine derivatives maintained their cytoprotective properties in MDCK (Madin-Darby canine kidney) cells, a distal tubular cell line. Moreover, they showed that small modifications to the molecule near the interacting centre for receptor binding abolished the effect (Dong et al., 2001). These results clearly prove specific strychnine interactions with surface-oriented extracellular domains. Although the effects of these compounds are typically receptor dependent, in renal cells these effects do not seem to depend on chloride ion gradients, since replacement of chloride by gluconate could not abolish the effects. In an attempt to explain this apparent contradiction, it has been suggested that under ischemic conditions, dysregulation of GlyRs leads to the development of a pathological pore, allowing the penetration of macromolecules and, hence, cell death (Venkatachalam et al., 1996). This pore formation can be prevented by adding agonists as well as antagonists, which somehow stabilize the GlyR. This hypothesis was supported by Dong and co-authors, who showed that, in ischemic conditions, there is a size-dependent membrane penetration of macromolecular dextrans, with a progressive increase in permeability for larger dextran molecules during the period of ischemia. This permeability defect could be prevented by a cross-linking agent (3,3' dithiobis(sulfosuccinimidylpropionate)) or by adding millimolar glycine (Dong et al., 1998). Direct evidence for GlyR involvement was recently provided by a study that showed that inhibition of endogenous GlyR expression by RNA interference attenuates cytoprotection in MDCK cells (Pan et al., 2005). They also found that HEK (human embryonic kidney) cells were not protected from ischemic cell death by glycine, unless they were transfected with plasmid constructs expressing the GlyR $\alpha 1$ subunit. GlyR $\alpha 1$ mutants of Y202F or Y202L, which are shown to decrease glycine and strychnine binding, also specifically abolished the effects of glycine and strychnine, respectively, further suggesting the involvement of glycine receptor subunits in cytoprotection At the molecular level, most studies have only found evidence for GlyR $\beta$ subunit and gephyrin expression at the basolateral membrane of proximal tubule cells (Grenningloh et al., 1987; Miller and Schnellmann, 1994; Sarang et al., 1999). There is also in vivo evidence for a protective role of glycine against ischemic conditions in the kidney. For example, when rats were fed with a diet containing 5\% glycine, their renal function was improved [higher glomerular filtration rate (GFR) and lower plasma creatinine] after renal ischemia (Yin et al., 2002). These effects might also be relevant under normal physiological conditions since when normal rats are infused with glycine, a decrease in renal vascular resistance is observed, leading to an increase in renal plasma flow and, hence, in GFR. In addition, glycine also decreases proximal tubular reabsorption (Thomsen et al., 2002).

\section{CONCLUSION}

Numerous in vitro and in vivo studies provide evidence for a cytoprotective role of glycine against kidney ischemia. This effect seems to be mediated by GlyRs with unusual properties: (i) there is little evidence that GlyR $\alpha$ subunits are expressed in kidney cell types, (ii) glycine effects can be mimicked by both GlyR agonists and antagonists and (iii) these effects do not depend upon the chloride gradient. Currently, porous defects are thought to develop in plasma membranes of ischemic cells as a consequence of a molecular perturbation of GlyR channels, that lead to leakage of macromolecules and, hence, to cell death. Glycine and GlyR antagonists might stabilize this unusual GlyR of unknown subunit composition accounting for cytoprotective effects.

\section{HEPATOCYTES}

In the liver, ischemia-reperfusion injury is a serious problem after liver transplantation that often leads to primary graft dysfunction. Thus, glycine is a potential cytoprotective agent of particular interest for the liver. The specific role of glycine in hepatic ischemiareperfusion injury was recently reviewed (Habib et al., 2006). A few years after the first report of a cytoprotective role of glycine in renal ischemia, Marsh and colleagues showed that isolated hepatocytes exposed to cold ischemia in the presence of glycine $(3 \mathrm{mM})$ experienced a significant improvement of cellular injury compared to controls (Marsh et al., 1991). This effect was shown to be independent of glutathione synthesis (Marsh et al., 1991; Ozaki et al., 1994). Comparable effects were observed with high concentrations of alanine $(10 \mathrm{mM})$ and strychnine $(1 \mathrm{mM})$ as well as under conditions of metabolic inhibition (chemical hypoxia; Dickson et al., 1992; Marsh et al., 1993; Nagatomi et al., 1997; Sakaida et al., 1996). Also for hepatocytes, the strychnine effects were shown to be specific (Dong et al., 2001). Glycine hepatoprotective effects were independent of ATP levels or intracellular acidosis, and glycine could not protect against injury caused by calcium ionophores or by oxidative stress (Marsh et al., 1993; Sakaida et al., 1996). It was also shown that glycine could inhibit calcium-dependent non-lysosomal protease activity during ischemia (Ferguson et al., 1993; Nichols et al., 1994). High concentrations of glycine (2-10 mM), but also L-alanine $(10 \mathrm{mM})$ or strychnine $(1 \mathrm{mM})$, were shown to be protective and to non-specifically block influx of different ions (e.g. sodium, cobalt or nickel; Carini et al., 1997; Frank et al., 2000). Although it was shown that blocking sodium influx by itself was cytoprotective and was dependent upon chloride influx, glycine was still protective in a sodium- or chloride-free buffer. Glycine was hypothesized to block non-specific 'leak' channels, which might increase in number and permeability with time (Frank et al., 2000). Glycine protects hepatocytes form ischemic cell death, but it does not prevent the mitochondrial permeability transition (MPT), contrary to cellular acidosis or sodium-free culture conditions, both preventing the MPT (Qian et al., 1997). In a review on the role of the MPT in ischemic cell death 
of hepatocytes, it was argued that glycine acted downstream of the MPT, at a time point where cells are completely deprived of ATP and destined for necrotic cell death (Kim et al., 2003). Glycine was also shown to protect against hepatotoxicity induced by different agents (e.g. valproate, paracetamol, cadmium chloride or copper chloride), an effect that can only partly be explained by metabolic detoxification of acyl-coenzyme A by means of acylglycine formation (Deters et al., 1998; Vance et al., 1994). To date, only one study has described clear GlyR-related modulatory effects in hepatocytes. $\mathrm{Qu}$ and colleagues demonstrated that glycine blocks prostaglandin $\mathrm{E}_{2}$ - and epinephrine-induced calcium fluxes in hepatocytes, an effect that is chloride-dependent and antagonized by low concentrations of strychnine $(10 \mu \mathrm{M})$. However, no direct link between calcium modulation and cytoprotective effects could be made ( $\mathrm{Qu}$ et al., 2002). Molecular evidence for GlyRs in hepatocytes is scarce. A GlyR $\beta$ subunit splice variant was described in liver homogenates (Oertel et al., 2007), but its cellular origin is unclear (hepatocytes, Kupffer cells or endothelial cells). To date, no GlyR $\alpha$ subunit gene expression has been described (Froh et al., 2002; Grenningloh et al., 1987). In vivo evidence also supports a protective role of glycine against liver ischemia and other pathologies. Several animal studies have shown that glycine has beneficial effects during liver transplantation. When given intravenously to donors or when given to acceptors (den Butter et al., 1993; Ito et al., 2008; Schemmer et al., 1999), glycine improved survival and decreased liver enzyme concentrations. It is however noteworthy that besides a direct cytoprotective effect on hepatocytes, there is also an important immunomodulatory contribution via the suppression of Kupffer cell activity in vivo. Indeed, a positive correlation was found between the protective effects of glycine and the decrease in Kupffer cell-derived TNF $\alpha$ and proteases (Duenschede et al., 2006; Schemmer et al., 1999; Yamanouchi et al., 2007). Further evidence for Kupffer cell involvement in beneficial glycine effects came from an animal study that showed that glycine, when given to donors, decreases levels of TNF $\alpha$ and liver enzymes, an effect that can be blocked by adding low levels of strychnine ( $5 \mu \mathrm{M}$; Zhang et al., 2005). As strychnine antagonism is only established for immunomodulatory effects on Kupffer cells, but not for cytoprotective effects on hepatocytes, these findings strongly support a crucial role for Kupffer cells. As mentioned earlier, beneficial effects of glycine in alcoholic liver disease were mainly due to Kupffer cells as well. Also in animal models of endotoxine and hemorrhagic shock, glycine modulation of Kupffer cells and inhibition of TNF $\alpha$-secretion seem to be crucial for its beneficial effects (Mauriz et al., 2001; Neyrinck et al., 2005; Wang et al., 2004; Yang et al., 2001; Zhong et al., 1999). On the other hand, it was shown that destruction of Kupffer cells by gadolinium chloride ( $\mathrm{GdCl}$ ) was far less potent than glycine in animal liver transplantation studies, suggesting that not all in vivo findings can be explained by modulation of Kupffer cells (Rentsch et al., 2002, 2005). Also, in animal models of cholestasis, where bile cannot flow from the liver to the duodenum it was shown that beneficial glycine effects (lowering of TNF $\alpha$ levels, liver necrosis and liver enzymes) remained when Kupffer cells were destructed by $\mathrm{GdCl}$ (Fang et al., 2003; Froh et al., 2008). Finally, some of the cytoprotective effects of glycine could also be attributed to glycine interacting with (sinusoidal) endothelial cells (see "Endothelial cells"). The above-mentioned cytoprotective effects of glycine against liver ischemia were considered solid enough to trigger clinical trials. Preliminary studies with few patients were undertaken showing, in one first study, that $2 \mathrm{mM}$ glycine added to the perfusion solution during transplantation induced a significant decrease in liver enzymes and evoked less complications (Arora et al., 1999). A second study with seven patients confirmed that a oneweek long daily infusion of glycine post-operatively (corresponding to $\sim 2 \mathrm{mM}$ plasma concentration) significantly decreased plasma liver enzyme levels (Schemmer et al., 2001,2002). These preliminary results led to a multicenter, randomized, placebo-controlled double blind clinical trial that is currently under investigation (HEGPOL, "Hepatoprotective Effects of Glycine in the Postoperative Phase"; Luntz et al., 2005).

\section{CONCLUSION}

In the liver, glycine protects against ischemic injury what may have clinical applications to reduce complications in liver transplantation with preliminary clinical trials showing promising results. However, the molecular mechanism of the glycine effect remains elusive and nothing is known about the precise role or composition of hepatic GlyRs. As for the kidney, one hypothesis is that glycine could block non-specific pore formation, preventing plasma membrane leakage and, eventually, cell death. Besides direct cytoprotective effects on hepatocytes, glycine modulatory effects on Kupffer and endothelial cells have to be taken into account especially in in vivo studies.

\section{ENDOTHELIAL CELLS}

By analogy to the situation in the liver and in the kidney, glycine was also suggested to have cytoprotective effects in endothelial cells subjected to hypoxia or challenged with ionomycine, cyanide, hydrogen peroxide or maitotoxin (Estacion et al., 2003; Nishimura and Lemasters, 2001; Nishimura et al., 1998; Weinberg et al., 1992). These effects were independent of $\mathrm{pH}$, ATP levels or calcium and could be mimicked by L-alanine. Estacion and co-workers found that glycine protective effects on cell death were taking place at the late phase of maitotoxin cytotoxicity and could prevent poreformation in the cytoplasmic membrane, which would normally lead to cell death. Nishimura and co-workers also hypothesized that glycine could block the opening of a "death channel" during hypoxia. They found that sinusoidal endothelial cells were going through different stages during ischemia. During early hypoxia, a cation influx appears as a consequence of a decrease in $\mathrm{Na}^{+} / \mathrm{K}^{+}$ ATPase activity. However, this is not accompanied by an anion influx and causes only moderate cell swelling. In a next stage, called the metastable state (characterized by the MPT), anions start flowing inside cells through a "death channel" leading to an increase in colloid osmotic pressure, to bleb formation and, eventually, to the rupture of plasma membranes and to cell death. Based on the finding that glycine slows anionic calcein entrance, decreases bleb formation and prevents entrance of propidium iodide and macromolecules into cells, it was suggested that glycine could somehow inhibit this "death channel" (Nishimura and Lemasters, 2001). Besides protecting against ischemic necrosis, glycine also seems to prevent apoptosis of sinusoidal endothelial cells induced by vascular endothelial growth factor (VEGF) deprivation. This protective effect is blocked by strychnine $(1 \mu \mathrm{M})$ and is possibly mediated by enhanced bcl-2 expression (Zhang et al., 2000). In this context, VEGF-induced cellular calcium influxes can be completely 
prevented by addition of $1 \mathrm{mM}$ of glycine in CPA cells, a bovine endothelial cell line. This effect is clearly GlyR-dependent since it can be blocked by micromolar concentrations of strychnine and is eliminated in chloride-free buffer conditions. Furthermore, GlyR $\beta$ subunit expression was found at the mRNA and protein level and glycine could decrease the proliferation and the migration of endothelial cells (Yamashina et al., 2001). This inhibiting effect of glycine on endothelial cells may explain why glycine was found to be tumour suppressive in melanoma and liver tumours. In this respect, it is of interest to mention that glycine inhibited tumour growth in the advanced stages only, which is when neo-angiogenesis has an important role in tumour progression because of oxygen need (Rose et al., 1999a,b). Later, it was demonstrated that glycine could indeed inhibit angiogenesis, leading to a decreased wound healing and tumour growth (Amin et al., 2003), suggesting that glycine effects on endothelial cells may be of future interest for research into atherosclerosis (McCarty et al., 2009). Glycine-mediated vascular effects were also attributed to NMDA receptors (NMDARs) in some studies. For example, Mishra and colleagues showed that glycine lowers the blood pressure in normotensive rats, while it increases it in hypertensive and L-NAME (NO synthase inhibitor)-treated rats. These effects were attributed to NMDAR activation on both endothelial and vascular smooth muscle cells, with the former being $\mathrm{NO}$-dependent and prevailing under normotensive conditions and the latter prevailing under hypertensive conditions (Mishra et al., 2008). NMDAR-mediated vascular effects were also suggested to mediate glycine vasodilatory effects and, hence, to increase GFR in the kidney (Deng et al., 2002; Slomowitz et al., 2004).

\section{CONCLUSION}

In endothelial cells, some modulating effects of glycine are present that appear to be mediated by GlyRs. Potential effects of glycine on migration and proliferation may explain beneficial glycine effects on tumour growth and wound healing. As in the liver and in the kidney, some of the cytoprotective effects of glycine could be mediated by a non-specific pore formed under ischemic conditions.

\section{OTHER CELL TYPES}

In cardiomyocytes, a few recent studies showed beneficial glycine effects under ischemia-reperfusion conditions. For example, $3 \mathrm{mM}$ glycine increases the cell viability of isolated cardiomyocytes and of isolated rat hearts after ischemia/reperfusion (Ruiz-Meana et al., 2004). Based on the findings that glycine prevented mitochondrial swelling and calcein release, it was suggested that glycine somehow inhibits the MPT. However, this contrasts with other findings in the kidney and in the liver where the general assumption is that glycine acts downstream of the MPT (Kim et al., 2003). In another study, glycine infusion into animal donor hearts was beneficial for right ventricular function after transplantation (Warnecke et al., 2006). Lastly, a recent study showed that $2 \mathrm{mM}$ glycine could protect isolated rat heart function and viability in an experimental LPS-induced decreased cardiac function model. This protective effect of glycine was linked to an attenuation of LPS- and hypoxia-induced calcium influx. Interestingly, the authors again detected the presence of GlyR $\beta$ subunits, but not GlyR $\alpha$ subunits (Qi et al., 2007). GlyRs are also well described in sperm in humans, pigs, mice and golden hamsters where they are involved in the zona pellucida-initiated acrosome reaction, an indispensable step in the fertilization process. Glycine induces the acrosome reaction at micromolar concentrations and this effect can be blocked by very low concentrations of strychnine $(50 \mathrm{nM})$. In the spasmodic and spastic mouse models (characterized by GlyR $\alpha 1$ and $\beta$ subunit mutations, respectively), deficiencies in the acrosome reaction are found. Molecular studies have detected GlyR $\alpha 1, \alpha 3$ and $\beta$ subunits in the periacrosomal plasma membrane (Bray et al., 2002; Kumar and Meizel, 2008; Llanos et al., 2001, 2003; Meizel, 1997; Melendrez and Meizel, 1995, 1996; Sato et al., 2000a,b, 2002). Interestingly, GlyR $\alpha 4$ subunit transcripts were also found in the male genital ridge in chicken (Harvey et al., 2000). Finally, cytoprotective effects of glycine in ischemia-reperfusion injury have also been described in other organs, such as in the gastro-intestinal system, in skeletal muscle and the lungs (Ascher et al., 2001; Gohrbandt et al., 2006; Iijima et al., 1997; Lee et al., 2001, 2002; Mangino et al., 1996; Tariq and Al Moutaery, 1997). However, in those models, no clear cellular targets for glycine have been identified, so indirect effects via immune cells or even the nervous system have not been eliminated.

\section{CONCLUSION}

The effects of glycine, mediated by classical or unconventional GlyRs, have been described in many different non-neuronal cell types and both inside and outside the nervous system. Broadly, glycine effects can be classified into two main types: cytoprotective and modulatory, an overview of which can be found in Table 1.

Modulatory effects of glycine were mainly found in immune cells such as macrophages and are associated with clear molecular and pharmacological evidence of functional GlyRs. For example, glycine in macrophages induces uptake of ${ }^{36} \mathrm{Cl}^{-}$and inhibits calcium flux in a dose-dependent manner, in a concentration range of 0.1 and $1 \mathrm{mM}$. Pharmacological findings also support the involvement of GlyRs in these effects: blockage is observed by low concentrations of strychnine $(1 \mu \mathrm{M})$, similar effects are elicited by taurine and $\beta$ alanine, but not by L-alanine, and these effects are eliminated by replacement of chloride in buffers. At the molecular level, both GlyR $\alpha$ and $\beta$ subunits have been described on these cells, although there may be important species differences. Besides immune cells, comparable modulatory effects were observed in glial cells, endothelial cells and spermatozoa. Although the GlyRs on these cells are clearly identical in subunit composition to selected neuronal GlyRs, it is remarkable that, to our knowledge, no direct electrophysiological evidence for functional GlyRs exists in immune cells. Although, technically, there is no problem performing patch-clamp experiments on these cells, the only non-neuronal cells where GlyR-mediated ionic currents have been directly measured are glial cells, and even in this case currents could only be recorded from spinal cord slices, as opposed to cultured cells. This suggests a complex regulation of GlyR expression in non-neuronal cells and further research is required to confirm the existence of functional GlyRs on these cell types. In this regard, an emphasis on correct cell culture conditions may represent the best way forward. Cytoprotective effects were mainly studied in renal cells, hepatocytes and endothelial cells, and have obvious clini$\mathrm{cal}$ and therapeutic importance in the protection that is provided under ischemic conditions. There is some evidence linking these effects to GlyRs, although these receptors seem to function in an entirely different mode as described for the classic neuronal GlyRs. 
Table 1 | Most often evoked mechanisms responsible for glycine effects in non-neuronal cells.

\begin{tabular}{|c|c|c|}
\hline & Cytoprotective effect & Modulatory effect \\
\hline \multirow[t]{3}{*}{ Cells most studied } & Renal cells & Immune cells \\
\hline & Hepatocytes & Macroglial cells \\
\hline & Endothelial cells & Endothelial cells \\
\hline Main effect & Protection against ischemic necrosis & $\begin{array}{l}\text { Modulation of proliferation, migration, differentiation, } \\
\text { apoptosis,... }\end{array}$ \\
\hline Active concentrations & Up to $10 \mathrm{mM}$ & $0.1-1 \mathrm{mM}$ \\
\hline Calcium flux modulation & No & Yes \\
\hline Uptake of 36-chloride & No & Yes \\
\hline Chloride dependency & No & Yes \\
\hline \multirow[t]{6}{*}{ Pharmacological findings } & No strychnine block described & Effects blocked by low concentrations of strychnine $(1 \mu \mathrm{M})$ \\
\hline & Effects mimicked by structurally related & Effects mimicked by taurine and $\beta$-alanine \\
\hline & amino acids (e.g. L-alanine, L-serine) & \\
\hline & Effects mimicked by high concentrations (1 mM) & \\
\hline & of strychnine and other chloride channel blockers & \\
\hline & No mimicking by taurine & \\
\hline Molecular findings & Only $\beta$-subunits & Both $\alpha$ - and $\beta$-subunits \\
\hline Electrophysiological findings & None & Only in slice preparations of macroglial cells \\
\hline \multirow[t]{2}{*}{ Suggested mechanism } & Glycine sensitive death pathway & GlyR dependent modulation of calcium signalling \\
\hline & Unknown role of GlyR (subunit)s & \\
\hline
\end{tabular}

Glycine effects also seem to be more non-specific in the sense that the observed effects can be mimicked by other structurally related amino acids (e.g. L-alanine) and are caused by higher concentrations of glycine (up to $10 \mathrm{mM}$ ). Other findings inconsistent with GlyR-mediated effects are the 'agonist-like' effects of strychnine in high concentrations ( $1 \mathrm{mM}$ ) and of non-specific chloride channel blockers, as well as the chloride-independent effects. At the molecular level, mainly GlyR $\beta$ subunits have been detected, which are not reported to form functional homomeric GlyRs in recombinant systems. It is however noteworthy that the GlyR $\beta$ subunit distribution in the CNS is far more extended compared to GlyR $\alpha$ subunits, suggesting that $\beta$ subunits may have some as yet unknown function (Malosio et al., 1991). The current hypothesis concerning the cytoprotective effects of glycine against ischemia is tenuous at best, since it requires the existence of a glycine-sensitive pore that is activated in later stages of ischemic cell death, leading to membrane leakage of macromolecules. Moreover, this pore is stabilized and/or blocked by glycine,
GlyR antagonists and some chloride blockers. Molecularly, this pore seems to be some multimeric protein, somehow associated with GlyR subunits which can stabilize the pore upon ligand binding. More research is certainly needed to further explore this intriguing hypothesis. Finally, when considering glycine-related effects in non-neuronal cells, it is important to realize that other mechanisms do exist, some of which maybe also important for the reported modulatory and cytoprotective effects, but fall beyond the scope of this review. These include the NMDAR-mediated glycine effect in the vascular system, transporter-mediated effects in microglial cells or possible metabolic effects in microglia or the liver.

\section{ACKNOWLEDGEMENTS}

This work was supported by grants of the FWO (Fonds voor Wetenschappelijk Onderzoek) Flanders, Belgian IAP (Interuniversitary Attraction Pole) and BOF (Bijzonder Onderzoeksfonds) Hasselt University and the Medical Research Council (G0500833).

\section{REFERENCES}

Alam, S., Laughton, D. L., Walding, A., and Wolstenholme, A. J. (2006). Human peripheral blood mononuclear cells express GABAA receptor subunits. Mol. Immunol. 43, 1432-1442.

Aleo, M. D., and Schnellmann, R. G. (1992). The neurotoxicants strychnine and bicuculline protect renal proximal tubules from mitochondrial inhibitor-induced cell death. Life Sci. 51, 1783-1787.

Amin,K.,Li,J.,Chao,W.R.,Dewhirst, M. W., and Haroon, Z. A. (2003). Dietary glycine inhibits angiogenesis during wound healing and tumor growth. Cancer Biol. Ther. 2, 173-178.
Aragon, C., and Lopez-Corcuera, B. (2003). Structure, function and regulation of glycine neurotransporters. Eur. J. Pharmacol. 479, 249-262.

Arora, A.S., Nichols, J. C., DeBernardi, M., Steers, J.L., Krom, R.A., and Gores, G. J. (1999). Glycine rinse protects against liver injury during transplantation. Transplant. Proc. 31, 505-506.

Ascher, E., Hanson, J. N., Cheng, W., Hingorani, A., and Scheinman, M. (2001). Glycine preserves function and decreases necrosis in skeletal muscle undergoing ischemia and reperfusion injury. Surgery 129, 231-235.

Bechade, C., Colin, I., Kirsch, J., Betz, H., and Triller, A. (1996). Expression of glycine receptor alpha subunits and gephyrin in cultured spinal neurons. Eur. J. Neurosci. 8, 429-435.

Belachew, S., Malgrange, B., Rigo, J. M. Rogister, B., Coucke, P., MazyServais, C., and Moonen, G. (1998a). Developmental regulation of neuroligand-induced responses in cultured oligodendroglia. Neuroreport 9, 973-980.

Belachew, S., Rogister, B., Rigo, J. M., Malgrange, B., Mazy-Servais, C., Xhauflaire, G., Coucke, P., and Moonen, G. (1998b). Cultured oligodendrocyte progenitors derived from cerebral cortex express a glycine receptor which is pharmacologically distinct from the neuronal isoform. Eur. J. Neurosci. 10, 3556-3564.

Belachew, S., Malgrange, B., Rigo, J. M., Rogister, B., Leprince, P., Hans, G. Nguyen, L., and Moonen, G. (2000) Glycine triggers an intracellular calcium influx in oligodendrocyte progenitor cells which is mediated by the activation of both the ionotropic glycine receptor and $\mathrm{Na}$--dependent transporters. Eur. J. Neurosci. 12, 1924-1930.

Betz, H., and Laube, B. (2006). Glycine receptors: recent insights into their structural organization and functional diversity. J. Neurochem. 97, 1600-1610. 
Bray, C., Son, J. H., Kumar, P., Harris, J. D. and Meizel, S. (2002). A role for the human sperm glycine receptor/Cl(-) channel in the acrosome reaction initiated by recombinant ZP3. Biol. Reprod. 66, 91-97.

Bruck, R., Wardi, J., Aeed, H., Avni, Y., Shirin,H.,Avinoach,I.,Shahmurov, M., and Hershkoviz, R. (2003). Glycine modulates cytokine secretion, inhibits hepatic damage and improves survival in a model of endotoxemia in mice. Liver Int. 23, 276-282.

Buttner, C., Sadtler, S., Leyendecker, A., Laube, B., Griffon, N., Betz, H., and Schmalzing, G. (2001). Ubiquitination precedes internalization and proteolytic cleavage of plasma membranebound glycine receptors. J. Biol. Chem. 276, 42978-42985.

Carini, R., Bellomo, G., Grazia De Cesaris, M., and Albano, E. (1997). Glycine protects against hepatocyte killing by KCN or hypoxia by preventing intracellular $\mathrm{Na}+$ overload in the rat. Hepatology 26, 107-112.

den Butter, G., Lindell, S. L., Sumimoto, R., Schilling, M. K., Southard, J. H., and Belzer, F. O. (1993). Effect of glycine in dog and rat liver transplantation. Transplantation 56, 817-822.

Deng, A., Valdivielso, J. M., Munger, K. A., Blantz, R. C., and Thomson, S. C. (2002). Vasodilatory N-methyl-Daspartate receptors are constitutively expressed in rat kidney. J. Am. Soc. Nephrol. 13, 1381-1384.

Deters, M., Siegers, C. P., and Strubelt, O. (1998). Influence of glycine on the damage induced in isolated perfused rat liver by five hepatotoxic agents. Toxicology 128, 63-72.

Dickson, R. C., Bronk, S. F., and Gores, G. J. (1992). Glycine cytoprotection during lethal hepatocellular injury from adenosine triphosphate depletion. Gastroenterology 102, 2098-2107.

Dong, Z., Patel, Y., Saikumar, P., Weinberg, J. M., and Venkatachalam, M. A. (1998). Development of porous defects in plasma membranes of adenosine triphosphate-depleted Madin-Darby canine kidney cells and its inhibition by glycine. Lab. Invest. 78, 657-668.

Dong, Z., Venkatachalam, M. A., Weinberg, J. M., Saikumar, P., and Patel, Y. (2001). Protection of ATPdepleted cells by impermeant strychnine derivatives: implications for glycine cytoprotection. Am J Pathol 158, 1021-1028.

Du, J. L., Xu, L. Y., and Yang, X. L. (2002). Glycine receptors and transporters on bullfrog retinal Muller cells. Neuroreport 13, 1653-1656.

Duenschede, F., Westermann, S., Riegler, N., Miesner, I., Erbes, K., Ewald, P., Kircher, A., Schaefer, H.,
Schneider, J., Schad, A., Dutkowski, P., Kiemer, A. K., and Junginger, T. (2006). Different protection mechanisms after pretreatment with glycine or alphalipoic acid in a rat model of warm hepatic ischemia. Eur. Surg. Res. 38, 503-512.

Estacion,M.,Weinberg,J.S.,Sinkins, W. G., and Schilling, W. P. (2003). Blockade of maitotoxin-induced endothelial cell lysis by glycine and L-alanine. Am. J. Physiol. Cell Physiol. 284, C1006-1020.

Fang, H. Q., Liu, Y. B., Li, H. J., Peng, S. Y., Wu, Y. L., Xu, B., Wang, J. W., Li, J. T., and Wang, X. B. (2003). Effects of glycine on plasma and liver tissue changes of TNF-alpha,ET-1 and nitric oxide contents in rats with obstructive jaundice. World J. Gastroenterol. 9, 2374-2376.

Ferguson, D. M., Gores, G. J., Bronk, S. F., and Krom, R. A. (1993). An increase in cytosolic protease activity during liver preservation. Inhibition by glutathione and glycine. Transplantation $55,627-633$.

Franek, F., Fismolova, I., and Eckschlager, T. (2002). Antiapoptotic and proapoptotic action of various amino acids and analogs in starving MOLT-4 cells. Arch. Biochem. Biophys. 398, 141-146.

Frank, A., Rauen, U., and de Groot, H. (2000). Protection by glycine against hypoxic injury of rat hepatocytes: inhibition of ion fluxes through nonspecific leaks. J. Hepatol. 32, 58-66.

Froh, M., Thurman, R. G., and Wheeler, M. D. (2002). Molecular evidence for a glycine-gated chloride channel in macrophages and leukocytes. Am. J. Physiol. Gastrointest. Liver Physiol. 283, G856-G863.

Froh, M., Zhong, Z., Walbrun, P., Lehnert, M., Netter, S., Wiest, R., Conzelmann, L., Gabele, E., Hellerbrand, C., Scholmerich, J., and Thurman, R. G. (2008). Dietary glycine blunts liver injury after bile duct ligation in rats. World J. Gastroenterol. 14, 5996-6003.

Gilbert, P., Kettenmann, H., and Schachner, M. (1984). gammaAminobutyric acid directly depolarizes cultured oligodendrocytes. J. Neurosci. 4, 561-569.

Gohrbandt, B., Fischer, S., Warnecke, G. Avsar, M., Sommer, S. P., Haverich, A., and Strueber, M. (2006). Glycine intravenous donor preconditioning is superior to glycine supplementation to low-potassium dextran flush preservation and improves graft function in a large animal lung transplantation model after 24 hours of cold ischemia. J. Thorac. Cardiovasc. Surg. $131,724-729$.
Grenningloh, G., Rienitz, A., Schmitt, B., Methfessel, C., Zensen, M. Beyreuther, K., Gundelfinger, E. D. and Betz, H. (1987). The strychninebinding subunit of the glycine receptor shows homology with nicotinic acetylcholine receptors. Nature 328 215-220.

Groot-Kormelink, P. J., Beato, M., Finotti, C., Harvey, R. J., and Sivilotti, L. G. (2002). Achieving optimal expression for single channel recording: a plasmid ratio approach to the expression of alpha 1 glycine receptors in HEK293 cells. J. Neurosci. Methods 113, 207-214.

Grudzinska, J., Schemm, R., Haeger, S. Nicke, A., Schmalzing, G., Betz, H. and Laube, B. (2005). The beta subunit determines the ligand binding properties of synaptic glycine receptors Neuron 45, 727-739.

Habib, M. M., Hodgson, H. J., and Davidson, B. R. (2006). The role of glycine in hepatic ischemiareperfusion injury. Curr. Pharm. Des. 12, 2953-2967.

Harvey, R. J., Depner, U. B., Wassle, H., Ahmadi, S., Heindl, C., Reinold, H. Smart, T. G., Harvey, K., Schutz, B. Abo-Salem, O. M., Zimmer, A. Poisbeau, P., Welzl, H., Wolfer, D. P., Betz,H.,Zeilhofer,H.U., and Muller, U. (2004). GlyR alpha3: an essential target for spinal PGE2-mediated inflammatory pain sensitization. Science 304 884-887.

Harvey, R. J., Schmieden, V., Von Holst, A., Laube, B., Rohrer, H., and Betz, H. (2000). Glycine receptors containing the alpha4 subunit in the embryonic sympathetic nervous system, spinal cord and male genital ridge. Eur J. Neurosci. 12, 994-1001.

Hayashi, Y., Ishibashi, H., Hashimoto, K., and Nakanishi, H. (2006). Potentiation of the NMDA receptor-mediated responses through the activation of the glycine site by microglia secreting soluble factors. Glia 53, 660-668.

Hijioka, T., Rosenberg, R.L.,Lemasters, J. J., and Thurman, R. G. (1992). Kupffer cells contain voltage-dependent calcium channels. Mol. Pharmacol. 41, 435-440.

Hoppe, D., and Kettenmann, H. (1989). GABA triggers a $\mathrm{Cl}-$ efflux from cultured mouse oligodendrocytes. Neurosci. Lett. 97, 334-339.

Iijima, S., Shou, J., Naama, H., Calvano, S. E., and Daly, J. M. (1997) Beneficial effect of enteral glycine in intestinal ischemia/reperfusion injury. J. Gastrointest. Surg. 1, 61-67; discussion 67-68.

Ikejima, K., Iimuro, Y., Forman, D. T., and Thurman, R. G. (1996). A diet containing glycine improves survival in endotoxin shock in the rat. Am. J. Physiol. 271, G97-G103.

Ikejima, K., Qu, W., Stachlewitz, R. F., and Thurman, R. G. (1997). Kupffer cells contain a glycine-gated chloride channel. Am. J. Physiol. 272, G1581-G1586.

Ito, K., Ozasa, H., Noda, Y., Koike, Y.,Arii, S., and Horikawa, S. (2008). Effect of nonessential amino acid glycine administration on the liver regeneration of partially hepatectomized rats with hepatic ischemia/reperfusion injury. Clin. Nutr. 27, 773-780.

Kettenmann, H., Backus, K. H., and Schachner, M. (1984a) Aspartate, glutamate and gamma-aminobutyric acid depolarize cultured astrocytes. Neurosci. Lett. 52, 25-29.

Kettenmann, H., Gilbert, P., and Schachner, M. (1984b) Depolarization of cultured oligodendrocytes by glutamate and GAB. A. Neurosci. Lett. 47, 271-276.

Kettenmann, H., Backus, K. H., and Schachner, M. (1987). Gamma-aminobutyric acid opens $\mathrm{Cl}$-channels in cultured astrocytes. Brain Res. 404, 1-9.

Kim, J. S., He, L., Qian, T., and Lemasters, J. J. (2003). Role of the mitochondrial permeability transition in apoptotic and necrotic death after ischemia/reperfusion injury to hepatocytes. Curr. Mol. Med. 3 , 527-535.

Kirchhoff, F., Mulhardt, C., Pastor, A., Becker, C. M., and Kettenmann, H. (1996). Expression of glycine receptor subunits in glial cells of the rat spinal cord. J. Neurochem. 66, 1383-1390.

Kirsch, J. (2006). Glycinergic transmission. Cell Tissue Res. 326, 535-540.

Kumar, P., and Meizel, S. (2008). Identification and spatial distribution of glycine receptor subunits in human sperm. Reproduction 136, 387-390.

Lee, M. A., McCauley, R. D., Kong, S. E. and Hall, J. C. (2001). Pretreatment with glycine reduces the severity of warm intestinal ischemic-reperfusion injury in the rat. Ann. Plast. Surg. 46, 320-326.

Lee, M. A., McCauley, R. D., Kong, S. E., and Hall, J. C. (2002). Influence of glycine on intestinal ischemia-reperfusion injury. JPEN I. Parenter. Enteral. Nutr. 26, 130-135.

Lee, S. C., Zhong, Y. M., and Yang, X. L. (2005). Expression of glycine receptor and transporter on bullfrog retinal Muller cells. Neurosci. Lett. 387, 75-79.

Legendre, P. (2001). The glycinergic inhibitory synapse. Cell. Mol. Life Sci. 58, 760-793.

Levi, S., Vannier, C., and Triller, A. (1998). Strychnine-sensitive stabilization of postsynaptic glycine receptor clusters. J. Cell Sci. 111,335-345. 
Lewis, R. S. (2001). Calcium signaling mechanisms in T lymphocytes. Annu. Rev. Immunol. 19, 497-521.

Li, X., Bradford, B. U., Wheeler, M. D., Stimpson, S. A., Pink, H. M., Brodie, T.A., Schwab, J. H., and Thurman, R.G. (2001). Dietary glycine prevents peptidoglycan polysaccharideinduced reactive arthritis in the rat: role for glycine-gated chloride channel. Infect. Immun. 69, 5883-5891.

Llanos, M. N., Ronco, A. M., and Aguirre, M.C. (2003). Specific strychnine binding sites on acrosome-associated membranes of golden hamster spermatozoa. Biochem. Biophys. Res. Commun. 306, 376-381.

Llanos, M. N., Ronco, A. M., Aguirre, M. C., and Meizel, S. (2001). Hamster sperm glycine receptor: evidence for its presence and involvement in the acrosome reaction. Mol. Reprod. Dev. 58, 205-215.

Luntz, S. P., Unnebrink, K., SeibertGrafe, M., Bunzendahl, H., Kraus, T. W., Buchler, M. W., Klar, E., and Schemmer, P. (2005). HEGPOL: randomized, placebo controlled, multicenter, double-blind clinical trial to investigate hepatoprotective effects of glycine in the postoperative phase of liver transplantation [ISRCTN69350312]. BMC Surg. 5, 18.

Lynch, J. W. (2004). Molecular structure and function of the glycine receptor chloride channel. Physiol. Rev. 84, 1051-1095.

Malosio, M. L., Marqueze-Pouey, B., Kuhse, J., and Betz, H. (1991). Widespread expression of glycine receptor subunit mRNAs in the adult and developing rat brain. EMBO J. 10, 2401-2409.

Mangino, J. E., Kotadia, B., and Mangino, M.J. (1996). Characterization of hypothermic intestinal ischemia-reperfusion injury in dogs. Effects of glycine. Transplantation 62, 173-178.

Marsh, D. C., Hjelmhaug, J. A., Vreugdenhil, P. K., Belzer, F. O., and Southard, J. H. (1991). Glycine prevention of cold ischemic injury in isolated hepatocytes. Cryobiology 28, 105-109.

Marsh,D.C.,Vreugdenhil,P.K.,Mack, V.E., Belzer, F. O., and Southard, J. H. (1993). Glycine protects hepatocytes from injury caused by anoxia, cold ischemia and mitochondrial inhibitors, but not injury caused by calcium ionophores or oxidative stress. Hepatology 17, 91-98.

Mauriz, J. L., Matilla, B., Culebras, J. M., Gonzalez, P., and Gonzalez-Gallego, J. (2001). Dietary glycine inhibits activation of nuclear factor kappa B and prevents liver injury in hemorrhagic shock in the rat. Free Radic. Biol. Med. 31, 1236-1244.

McCarty, M. F., Barroso-Aranda, J., and Contreras, F. (2009). The hyperpolarizing impact of glycine on endothelial cells may be anti-atherogenic. Med. Hypotheses 73, 263-264.

Meizel, S. (1997). Amino acid neurotransmitter receptor/chloride channels of mammalian sperm and the acrosome reaction. Biol. Reprod. 56, 569-574.

Melendrez, C. S., and Meizel, S. (1995). Studies of porcine and human sperm suggesting a role for a sperm glycine receptor/Cl- channel in the zona pellucida-initiated acrosome reaction. Biol. Reprod. 53, 676-683.

Melendrez, C. S., and Meizel, S. (1996). Immunochemical identification of the glycine receptor/Cl-channel in porcine sperm. Biochem. Biophys. Res. Commun. 223, 675-678.

Miller, G. W., and Schnellmann, R. G. (1994). A putative cytoprotective receptor in the kidney: relation to the neuronal strychnine-sensitive glycine receptor. Life Sci. 55, 27-34.

Mishra, R. C., Tripathy, S., Quest, D., Desai, K. M., Akhtar, J., Dattani, I. D., and Gopalakrishnan, V. (2008). L-Serine lowers while glycine increases blood pressure in chronic L-NAME-treated and spontaneously hypertensive rats. J. Hypertens. 26, 2339-2348.

Nagatomi, A., Sakaida, I., Matsumura, Y., and Okita, K. (1997). Cytoprotection by glycine against hypoxia-induced injury in cultured hepatocytes. Liver 17, 57-62.

Newell, E. W., and Schlichter, L. C. (2005). Integration of $\mathrm{K}+$ and $\mathrm{Cl}-$ currents regulate steady-state and dynamic membrane potentials in cultured rat microglia. J. Physiol. 567, 869-890.

Neyrinck, A. M., Margagliotti, S., and Delzenne, N. M. (2005). Insight into the involvement of Kupffer cell-derived mediators in the hepatoprotective effect of glycine upon inflammation: study on rat precision-cut liver slices. Inflamm. Res. 54, 106-112.

Nguyen, L., Malgrange, B., Belachew, S., Rogister, B., Rocher, V., Moonen, G., and Rigo, J. M. (2002). Functional glycine receptors are expressed by postnatal nestin-positive neural stem/ progenitor cells. Eur. J. Neurosci. 15, 1299-1305.

Nguyen, L., Rigo, J. M., Rocher, V., Belachew,S., Malgrange,B., Rogister, B., Leprince, P., and Moonen, G. (2001). Neurotransmitters as early signals for central nervous system development. Cell Tissue Res. 305, 187-202.

Nichols, J. C., Bronk, S. F., Mellgren, R. L., and Gores, G. J. (1994). Inhibition of nonlysosomal calcium-dependent proteolysis by glycine during anoxic injury of rat hepatocytes. Gastroenterology 106, 168-176.

Nishimura, Y., and Lemasters, J. J. (2001). Glycine blocks opening of a death channel in cultured hepatic sinusoidal endothelial cells during chemical hypoxia. Cell Death Differ. 8, 850-858.

Nishimura, Y., Romer, L. H., and Lemasters, J. J. (1998). Mitochondrial dysfunction and cytoskeletal disruption during chemical hypoxia to cultured rat hepatic sinusoidal endothelial cells: the $\mathrm{pH}$ paradox and cytoprotection by glucose, acidotic $\mathrm{pH}$., and glycine. Hepatology 27, 1039-1049.

Oertel, J., Villmann, C., Kettenmann, H., Kirchhoff, F., and Becker, C. M. (2007). A novel glycine receptor beta subunit splice variant predicts an unorthodox transmembrane topology. Assembly into heteromeric receptor complexes. J. Biol. Chem. 282, 2798-2807.

Ozaki, M., Ozasa, H., Fuchinoue, S., Teraoka, S., and Ota, K. (1994). Protective effects of glycine and esterified gamma-glutamylcysteine on ischemia/reoxygenation injury of rat liver. Transplantation 58, 753-755.

Paller, M. S. (1986). Hypothyroidism protects against free radical damage in ischemic acute renal failure. Kidney Int. 29, 1162-1166.

Pan, C., Bai, X., Fan, L., Ji, Y., Li, X., and Chen, Q. (2005). Cytoprotection by glycine against ATP-depletioninduced injury is mediated by glycine receptor in renal cells. Biochem. J. 390, 447-453.

Pastor, A., Chvatal, A., Sykova, E., and Kettenmann, H. (1995). Glycine- and GABA-activated currents in identified glial cells of the developing rat spinal cord slice. Eur. J. Neurosci. 7 , 1188-1198.

Pilas, B., and Durack, G. (1997). A flow cytometric method for measurement of intracellular chloride concentration in lymphocytes using the halide-specific probe 6-methoxy- $N$ (3-sulfopropyl) quinolinium (SPQ). Cytometry 28, 316-322.

Qi, R. B., Zhang, J. Y., Lu, D. X. Wang, H. D., Wang, H. H., and Li, C. J. (2007). Glycine receptors contribute to cytoprotection of glycine in myocardial cells. Chin. Med. J. (Engl.) 120, 915-921.

Qian, T., Nieminen,A. L., Herman, B., and Lemasters, J. J. (1997). Mitochondrial permeability transition in $\mathrm{pH}$ dependent reperfusion injury to rat hepatocytes. Am. J. Physiol. 273, C1783-C1792.

Qu, W., Ikejima, K., Zhong, Z., Waalkes, M. P., and Thurman, R. G.
(2002). Glycine blocks the increase in intracellular free $\mathrm{Ca} 2+$ due to vasoactive mediators in hepatic parenchymal cells. Am. J. Physiol. Gastrointest. Liver. Physiol. 283, G1249-G1256.

Rentsch, M., Beham, A., Sirek, S., Iesalnieks, I., Geissler, E. K., Anthuber, M., and Jauch, K. W. (2002). Glycine but not gadolinium chloride or methyl palmitate reduces postischemic white blood cell accumulation and early graft nonfunction after liver transplantation in the rat. Transplant. Proc. 34, 2389-2390.

Rentsch, M., Puellmann, K., Sirek, S., Iesalnieks, I., Kienle, K., Mueller, T., Bolder, U., Geissler, E., Jauch, K. W. and Beham, A. (2005). Benefit of Kupffer cell modulation with glycine versus Kupffer cell depletion after liver transplantation in the rat: effects on postischemic reperfusion injury, apoptotic cell death graft regeneration and survival. Transpl. Int. 18, 1079-1089.

Rose, M. L., Madren, J., Bunzendahl, H., and Thurman, R. G. (1999a). Dietary glycine inhibits the growth of B16 melanoma tumors in mice. Carcinogenesis 20, 793-798.

Rose, M. L., Cattley, R. C., Dunn, C., Wong, V., Li, X., and Thurman, R. G. (1999b). Dietary glycine prevents the development of liver tumors caused by the peroxisome proliferator WY-14,643. Carcinogenesis 20, 2075-2081.

Ruiz-Meana, M., Pina, P., GarciaDorado, D., Rodriguez-Sinovas, A., Barba, I., Miro-Casas, E., Mirabet, M. and Soler-Soler, J. (2004). Glycine protects cardiomyocytes against lethal reoxygenation injury by inhibiting mitochondrial permeability transition. J. Physiol. 558, 873-882.

Sahebali, S., Buckinx, R., Van den Eynden, J., and Rigo, J. M. (2007). Expression of glycine receptor and transporters in different oligodendroglial cell lines. Neuron Glia Biol. 2, S169.

Sakaida, I., Nagatomi, A., and Okita, K. (1996). Protection by glycine against chemical ischemia produced by cyanide in cultured hepatocytes. J. Gastroenterol. 31, 684-690.

Salceda, R., and Aguirre-Ramirez, M. (2005). Characterization of strychnine-sensitive glycine receptor in the intact frog retina: modulation by protein kinases. Neurochem. Res. 30, 411-416.

Sarang, S. S., Miller, G. W., Grant, D. F., and Schnellmann, R.G. (1999). Expression and localization of the neuronal glycine receptor beta-subunit in human, rabbit and rat kidneys. Nephron 82 , 254-260. 
Sato, Y., Son, J. H., and Meizel, S. (2000a) The mouse sperm glycine receptor/ chloride channel: cellular localization and involvement in the acrosome reaction initiated by glycine. J. Androl. 21, 99-106.

Sato, Y., Son, J. H., Tucker, R. P., and Meizel, S. (2000b) The zona pellucida-initiated acrosome reaction: defect due to mutations in the sperm glycine receptor/Cl(-) channel. Dev. Biol.227, 211-218.

Sato, Y., Tucker, R. P., and Meizel, S. (2002). Detection of glycine receptor/Clchannel beta subunit transcripts in mouse testis. Zygote 10, 105-108.

Schemmer, P., Bradford, B. U., Rose, M. L. Bunzendahl, H., Raleigh, J. A., Lemasters, J. J., and Thurman, R. G. (1999). Intravenous glycine improves survival in rat liver transplantation. Am. J. Physiol. 276, G924-G932.

Schemmer, P., Golling, M., Kraus, T., Mayatepek, E., Herfarth, C., and Klar, E. (2001). Glycine reduces reperfusion injury in human liver transplantation: our first patients. Transplant. Proc. 33, 3750-3752.

Schemmer, P., Golling, M., Kraus, T., Mehrabi, A., Mayatepek, E., Herfarth, C., and Klar, E. (2002). Extended experience with glycine for prevention of reperfusion injury after human liver transplantation. Transplant. Proc. 34, 2307-2309.

Schilling, T., and Eder, C. (2004). A novel physiological mechanism of glycine-induced immunomodulation: $\mathrm{Na}+$-coupled amino acid transporter currents in cultured brain macrophages. J. Physiol. 559, 35-40.

Seabra, V., Stachlewitz, R. F., and Thurman, R.G. (1998). Taurine blunts LPS-induced increases in intracellular calcium and TNF-alpha production by Kupffer cells. J. Leukoc. Biol. 64, 615-621.

Simon, J., Wakimoto, H., Fujita, N., Lalande, M., and Barnard, E.A. (2004). Analysis of the set of GABA(A) receptor genes in the human genome. J. Biol. Chem. 279, 41422-41435

Slomowitz,L.A., Gabbai, F.B., Khang, S. J., Satriano, J., Thareau, S., Deng,A., Thomson, S. C., Blantz, R. C., and Munger, K. A. (2004). Protein intake regulates the vasodilatory function of the kidney and NMDA receptor expression. Am. J. Physiol. Regul. Integr. Comp. Physiol. 287, R1184-R1189.

Sommer, M. H., Xavier, M. H., Fialho, M. B., Wannmacher, C. M., and Wajner, M. (1994). The influence of amino acids on mitogen-activated proliferation of human lymphocytes in vitro. Int. J. Immunopharmacol. 16, 865-872.
Spittler, A., Reissner, C. M., Oehler, R., Gornikiewicz, A., Gruenberger, T., Manhart, N., Brodowicz, T., Mittlboeck, M.,Boltz-Nitulescu, G., and Roth, E. (1999). Immunomodulatory effects of glycine on LPS-treated monocytes: reduced TNF-alpha production and accelerated IL-10 expression. FASEB J. 13, 563-571.

Stachlewitz, R. F., Li, X., Smith, S., Bunzendahl, H., Graves, L. M., and Thurman, R. G. (2000). Glycine inhibits growth of $\mathrm{T}$ lymphocytes by an IL-2-independent mechanism. J. Immunol. 164, 176-182.

Stachlewitz, R. F., Seabra, V., Bradford, B., Bradham, C. A., Rusyn, I., Germolec, D., and Thurman, R. G. (1999). Glycine and uridine prevent D-galactosamine hepatotoxicity in the rat: role of Kupffer cells. Hepatology 29, 737-745.

Sugishita, H., Kuwabara, Y., Toku, K., Doi, L., Yang, L., Mitoma, J. Furuya, S., Hirabayashi, Y., Maeda, N., Sakanaka, M., and Tanaka, J. (2001). $\mathrm{L}$-Serine regulates the activities of microglial cells that express very low level of 3-phosphoglycerate dehydrogenase, an enzyme for L-serine biosynthesis. J. Neurosci. Res. 64, 392-401.

Tanaka, J., Toku, K., Matsuda, S., Sudo, S., Fujita,H.,Sakanaka,M., and Maeda, N. (1998). Induction of resting microglia in culture medium devoid of glycine and serine. Glia 24, 198-215.

Tariq, M., and Al Moutaery, A. R. (1997). Studies on the antisecretory, gastric anti-ulcer and cytoprotective properties of glycine. Res. Commun. Mol. Pathol. Pharmacol. 97, 185-198.

Thomsen, K., Nielsen, C. B., and Flyvbjerg, A. (2002). Effects of glycine on glomerular filtration rate and segmental tubular handling of sodium in conscious rats. Clin. Exp. Pharmacol. Physiol. 29, 449-454.

Tian, J., Chau, C., Hales, T. G., and Kaufman, D. L. (1999). GABA(A) receptors mediate inhibition of $\mathrm{T}$ cell responses. J. Neuroimmunol. 96, 21-28.

Van den Eynden, J., Balthazar, T., Janssen, D., Nelissen, K., Smolders, I., and Rigo, J. (2008). Glycine modulates microglial activity by a glycine receptor independent mechanism. Acta Physiol. 194, P-07.

Vance, M.A., Gray, P.D., and Tolman, K. G. (1994). Effect of glycine on valproate toxicity in rat hepatocytes. Epilepsia 35, 1016-1022.

Venkatachalam, M. A., Weinberg, J. M., Patel, Y., Hussong, U., and Davis, J. A. (1995). Effects of $\mathrm{Ca}^{++}$and glycine on lipid breakdown and death of ATPdepleted MDCK cells. Kidney Int. 48, 118-128.
Venkatachalam, M. A., Weinberg, J. M. Patel, Y., Saikumar, P., and Dong, Z. (1996). Cytoprotection of kidney epithelial cells by compounds that target amino acid gated chloride channels. Kidney Int. 49, 449-460.

Wang, G., Zhao, M., and Wang, E. H. (2004). Effects of glycine and methylprednisolone on hemorrhagic shock in rats. Chin. Med. J. (Engl.) 117, 1334-1341.

Warnecke, G., Schulze, B., Steinkamp, T., Haverich, A., and Klima, U. (2006). Glycine application and right heart function in a porcine heart transplantation model. Transpl. Int. 19 218-224.

Weinberg, J. M., Buchanan, D. N., Davis, J. A., and Abarzua, M. (1991a). Metabolic aspects of protection by glycine against hypoxic injury to isolated proximal tubules. J. Am. Soc. Nephrol. 1, 949-958.

Weinberg, J. M., Venkatachalam, M. A. Roeser, N. F., Davis, J. A., Varani, J., and Johnson, K. J. (1991b). Amino acid protection of cultured kidney tubule cells against calcium ionophore-induced lethal cell injury. Lab. Invest. 65, 671-678.

Weinberg, J. M., Davis, J.A., Abarzua, M. and Rajan, T. (1987). Cytoprotective effects of glycine and glutathione against hypoxic injury to renal tubules. J. Clin. Invest. 80 1446-1454.

Weinberg, J. M., Davis, J. A., Abarzua, M. Smith, R. K., and Kunkel, R. (1990a). Ouabain-induced lethal proximal tubule cell injury is prevented by glycine. Am. J. Physiol. 258, F346-355.

Weinberg, J. M., Venkatachalam, M. A. Garzo-Quintero, R., Roeser, N. F., and Davis, J. A. (1990b). Structural requirements for protection by small amino acids against hypoxic injury in kidney proximal tubules. FASEB J. 4, 3347-3354.

Weinberg, J. M., Roeser, N. F., Davis, J. A. and Venkatachalam, M. A. (1997) Glycine-protected, hypoxic, proximal tubules develop severely compromised energetic function. Kidney Int. 52, 140-151.

Weinberg, J. M., Varani, J., Johnson, K. J., Roeser, N. F., Dame, M. K., Davis, J. A., and Venkatachalam, M. A. (1992). Protection of human umbilical vein endothelial cells by glycine and structurally similar amino acids against calcium and hydrogen peroxide-induced lethal cell injury. Am. J. Pathol. 140, 457-471.

Wheeler, M., Stachlewitz, R. F., Yamashina, S., Ikejima, K., Morrow, A. L., and Thurman, R. G. (2000a). Glycine-gated chloride channels in neutrophils attenuate calcium influx and superoxide production. FASEB J. 14, 476-484.

Wheeler, M.D., Rose, M. L., Yamashima, S. Enomoto, N., Seabra, V., Madren, J., and Thurman, R. G. (2000b) Dietary glycine blunts lung inflammatory cell influx following acute endotoxin. Am J. Physiol. Lung Cell. Mol. Physiol. 279, L390-L398.

Wheeler, M. D. (2003). Endotoxin and Kupffer cell activation in alcoholic liver disease. Alcohol Res. Health 27, 300-306.

Wheeler, M. D., Ikejema, K., Enomoto, N., Stacklewitz, R. F., Seabra, V., Zhong, Z., Yin, M., Schemmer, P., Rose, M. L., Rusyn, I., Bradford, B., and Thurman, R.G. (1999). Glycine: a new anti-inflammatory immunonutrient. Cell. Mol. Life Sci. 56, 843-856.

Wheeler, M. D., and Thurman, R. G. (1999). Production of superoxide and TNF-alpha from alveolar macrophages is blunted by glycine. Am. J. Physiol. 277, L952-L959.

Xu, F. L., You, H. B., Li, X. H., Chen, X. F., Liu, Z. J., and Gong, J. P. (2008). Glycine attenuates endotoxin-induced liver injury by downregulating TLR4 signaling in Kupffer cells. Am. J. Surg. 196, 139-148.

Yamanouchi, K., Eguchi, S., Kamohara, Y., Yanaga, K., Okudaira, S., Tajima, Y., and Kanematsu, T. (2007). Glycine reduces hepatic warm ischaemiareperfusion injury by suppressing inflammatory reactions in rats. Liver Int. 27, 1249-1254.

Yamashina, S., Ikejima, K., Enomoto, N., Takei, Y., and Sato, N. (2005). Glycine as a therapeutic immuno-nutrient for alcoholic liver disease. Alcohol Clin. Exp. Res. 29, 162S-165S.

Yamashina, S., Konno, A., Wheeler, M. D. Rusyn, I., Rusyn, E. V., Cox, A. D., and Thurman, R. G. (2001). Endothelial cells contain a glycine-gated chloride channel. Nutr. Cancer 40, 197-204.

Yan, L., Suneja, S. K., and Potashner, S. J. (2007). Protein kinases regulate glycine receptor binding in brain stem auditory nuclei after unilateral cochlear ablation. Brain Res. 1135 102-106.

Yang,L., Tanaka,J.,Zhang,B.,Sakanaka, M., and Maeda, N. (1998). Astrocytes modulate nitric oxide production by microglial cells through secretion of serine and glycine. Biochem. Biophys. Res. Commun. 251, 277-282.

Yang, S., Koo, D. J., Chaudry, I. H., and Wang, P. (2001). Glycine attenuates hepatocellular depression during early sepsis and reduces sepsis-induced mortality. Crit. Care Med. 29, 1201-1206.

Yin, M., Zhong, Z., Connor, H. D. Bunzendahl, H., Finn, W. F., Rusyn, I., 
Li, X., Raleigh, J. A., Mason, R. P., and Thurman, R. G. (2002). Protective effect of glycine on renal injury induced by ischemia-reperfusion in vivo. Am. J. Physiol. Renal Physiol. 282, F417-F423.

Zhang, S. J., Shi, J. H., Tang, Z., Wu, Y., and Chen, S. (2005). Protective effects of glycine pretreatment on brain-death donor liver. Hepatobiliary Pancreat. Dis. Int. 4, 37-40.

Zhang, Y., Ikejima, K., Honda, H., Kitamura, T., Takei, Y., and Sato, N. (2000). Glycine prevents apoptosis of rat sinusoidal endothelial cells caused by deprivation of vascular endothelial growth factor. Hepatology 32, 542-546.

Zhong, Z., Enomoto, N., Connor, H. D. Moss, N., Mason, R. P., and Thurman, R. G. (1999). Glycine improves survival after hemorrhagic shock in the rat. Shock 12, 54-62.

Zhong, Z., Wheeler, M.D., Li, X., Froh, M., Schemmer, P., Yin, M., Bunzendaul, H., Bradford, B., and Lemasters, J.J. (2003). L-Glycine: a novel antiinflammatory, immunomodulatory, and cytopro- tective agent. Curr. Opin. Clin. Nutr. Metab. Care 6, 229-240.

Conflict of Interest Statement: The authors declare that the research was conducted in the absence of any commercial or financial relationships that could be construed as a potential conflict of interest.

Received: 24 June 2009; paper pending published: 13 July 2009; accepted: 23 July 2009; published online: 20 August 2009.

Citation: Van den Eynden J, SahebAli S, Horwood N, Carmans S, Brône B, Hellings
$N$, Steels P, Harvey RJ and Rigo I-M (2009) Glycine and glycine receptor signalling in non-neuronal cells. Front. Mol. Neurosci. 2:9. doi: 10.3389/neuro.02.009.2009

Copyright (C) 2009 Van den Eynden, SahebAli, Horwood, Carmans, Brône, Hellings, Steels, Harvey and Rigo. This is an open-access article subject to an exclusive license agreement between the authors and the Frontiers Research Foundation, which permits unrestricted use, distribution, and reproduction in any medium, provided the original authors and source are credited. 